\title{
POLITICS AND DEVELOPMENT
}

\section{Conformers and Pretenders: The Case of Middle Class Political Opposition in Swaziland, 1962-2000}

\author{
Hamilton Sipho Simelane \\ University of Swaziland, Kwaluseni - Swaziland
}

\begin{abstract}
In both the colonial and post-colonial periods different segments of the Swazi population have expressed political ideals. Throughout these periods Swazi politics has been characterized by the dominance of traditional political culture, but different groups have from time to time expressed political views opposed to the traditional political perspective. This has been the case with those who have received western education and constitute the Swazi middle class. From soon after the Second World War this class has been vocal in advocating for a political dispensation opposed to traditional politics centred on the monarchy.

Up to now no coherent study has attempted a critical analysis of middle class opposition politics in Swaziland. This is in spite of the fact that the middle class opposition has taken different interesting shades in both the colonial and post-colonial periods. This article focuses on this neglected but interesting subject as it brings out the real character of middle class political opposition in Swaziland. The article argues that middle class political opposition in Swaziland is not based on principles fundamentally different from those of traditional politics, but is largely shaped by the ambitions of the advocates to accumulate through the state pathway.
\end{abstract}

\section{Introduction}

In this country - Swaziland, the stomach rules (or determines our responses to situations). It rules not just with journalists but also with everybody. Just look 
around and see who is making noise today. It is the hungry ones! Their noise is not genuine. It is merely to attract attention. They all want a ride on the gravy train. It is now a case of "if you can't beat them, you join them." I say again, the stomach rules in this country. Complaining does not help. It is lip service and an exercise in futility (Times of Swaziland, hereafter, TOS), 7 February, 1999).

Social classes play a significant role in the development of both political and economic events because they are agents of change in countries where free-market economic relations are dominant. The growth of the middle class and its role in political change has been a subject of many studies in different parts of the world. Patterns of income distribution, educational attainment, and occupational status have expanded the ranks of the middle sectors. This has in turn led to the construction of a new agenda for political organisation and participation (Clegg, Borehand and Daro, 1986: 144-148). It has also been demonstrated that the middle class has played a crucial role in the politics of both industrialised and industrializing societies (Selsam, Goldway and Martel, 1983). This has been the case because the middle class has been desirous of attaining political power and influence (Lukacs, 1974). Political power has been viewed as a necessary base for formatting policies conducive to the interests of the same class (Hobsbawm, 1975: 287). In most Third World countries middle class opposition to traditional systems has been ambiguous, reflecting its dependence on the state apparatus for purposes of accumulation (Rasmussen, 1969; Vengroff, 1993: Mazrui, 1975; and Anise, 1974). Case studies on Africa (Hagreaves, 1979) and Latin America (Burns, 1982; Bushnell and Macaulay, 1988) have demonstrated that middle class opposition to the status quo was driven by the desire to control the state for purposes of accumulation.

In the case of Swaziland, the beginning of the 1960s saw the emergence of a political conflict between some members of the western educated middle class who formed modern political parties, and those who believed in the continuation and consolidation of indigenous political institutions under the leadership of the monarchy (Macmillan, 1986; Kuper, 1947). From the 1960s into the post-colonial period some members of the middle class constituted an opposition to the traditional political dispensation. One of their objectives was to destroy the monarchy "as a meaningful political force" (Potholm, 1972: 3). Consequently, an analysis of middle class political opposition in Swaziland can lead to a more deeper and mannered understanding of Swazi politics.

Several scholars have touched on the issue of political conflict in Swaziland, (Booth, 1983; Halpern, 1965; Macmillan, 1986; Potholm, 1966; Daniel, Simelane and Simelane, 1975; Stevens, 1966; Levin, 1997) but 
there is presently no study that deals with the relationship between middle class politics and traditional politics. The aim of this paper is to provide a critical analysis of the manner in which middle class opposition has interplayed with traditional politics. The paper argues that Swazi middle class opposition has opted to align itself with the traditional political order for purposes of personal economic accumulation. Leading middle class politicians have conformed or pretended to conform to the traditional political system whenever opportunities of accumulation through the state apparatus have been perceived. The arguments raised in the paper are not unique to Swaziland but they help to bring the otherwise forgotten Swazi experience into general academic discourse.

\section{Character of the Swazi middle class}

The Swazi middle class comprises numerous categories of people (Poulantzas, 1975). It includes those involved in the export-import trade, retail business, transport business, a small indigenous group of businessmen owing their wealth to local extractive and industrial enterprises often in partnership with foreigners, professionals in the bureaucracy, and lower salaried personnel in government ministries, parastatals, uniformed forces, and educational institutions. In the decade before independence white settlers described them as a "small educated African class which has separated from tribal ways" (Times of Swaziland, (hereafter TOS), 23 March, 1962).

The main characteristic of this group is that from its emergence it was a depended class with most of its members scrambling for positions within and through the state apparatus. Their income placed them between the traditional ruling class and the impoverished many. They lack both the historical maturity and objective economic base of their metropolitan counterparts (Fanon, 1967). Government intervention to bring about change is the most cherished principle (Mamdani, 1988). A position within the state apparatus acts as a lever for capital accumulation. Their power is derivative, coming to them from the top down and depends on policies set in the offices of the traditionalists. This class has opted for the path of accumulation from above, a form of accumulation that begins with political connections, and reduces the state to an apparatus for accumulation (Thomas, 1984; Shivji, 1976). The growth of state bureaucratic capitalism has been the main instrument for the development of the class (Schatz, 1977; Kennedy, 1988; Evans, 1979; Biesrsteker, 1982). Consequently, this class views the state as a primary motor force behind economic developments (Callaghy, 1984; Clapham, 1985; Sandbrook, 1985). These characteristics have shaped the political behaviour of the middle class opposition in Swaziland. 
The dependent nature of the Swazi middle class reflected in its reliance on the state arises from the fact that it did not emerge as a product of control of the means of production based on sound economic philosophies. It was partly a creation of the monarchy through its economic machinations. These circumstances of the class's development made it fail to achieve a consciousness completely divorced from the traditional order.

\section{Swazi middle class conformers and pretenders, 1964-1968}

The political culture of conforming to the traditional political framework for purposes of personal gain became observable in the early 1960s. During this period conformity was activated by members of the Mbandzeni National Convention, who disbanded their party before the 1964 elections (Potholm, 1966: 318). Justifying their actions the leader of the party argued that "I am convinced that the rapidly changing political climate in Swaziland calls for a more direct, militant, and dynamic approach than has hitherto been provided, and that because of this reason, most existing political organizations, including the convention, have become obsolete" (TOS, 12 December,1963). It was, however, immediately after the 1964 Legislative Council elections that the conformity and opportunism of middle class opposition became pronounced. In the elections, the king's party, the Imbokodvo National Movement won all the seats making it clear that the traditionalists were on the verge of inheriting political power from the British. The impact of the results on middle class opposition was well portrayed by Christian Potholm when he concluded that, "The defeat of the other parties was complete. Divided among themselves, lacking adequate funds, their leadership was humiliated" (Potholm, 1966: 316). To the majority of middle class opposition leaders, it became clear that the best chance of accumulation through the state apparatus was through aligning themselves with the traditionalists. The majority of the opposition leaders defected from their parties to join the camp of the traditionalists. They either resigned from their parties to join the king's party or had their parties merged with that of the king.

The first defection was that of Simon Sishayi Nxumalo, a founder member and president of the Swaziland Democratic Party. He resigned from his party in October 1964 and claimed that he lost in the elections because "he had put himself into the enemy camp and so was described as fighting the king" (Potholm, 1966: 259). He claimed that he was giving himself an opportunity to work for wider national unity. To prove his loyalty he immediately began to organize within the Imbokodvo to form what he called Ngwenyama National Voluntary Service. Its responsibility was to influence the Swazi, "To gather in one organisation, the energies of all men and women of Swaziland irrespective of race, creed or political allegiance, to fight against disease, poverty and ignorance through the 
means of a modern community development and educational scheme" (TOS, 19 February, 1965). He became one of the strongest defenders of traditional Swazi political practices up to his death in 2000. He was included in almost all cabinets of an independent Swaziland during his time.

Another defector who sent shock waves throughout Swaziland, especially among the more radical members of the middle class, was Dumisa Dlamini. Before his defection Dumisa was one of the most militant and articulate member of the Ngwane National Liberatory Congress. Before his defection, this person was one of the most militant and radical members of the Ngwane National Liberatory Congress (NNLC) and occupied influential positions within the party. He was a member of the royal family but very active in the struggle of workers against low wages and poor working conditions. In 1963 he was at the forefront of the labour unrest that shook British colonialism in the country. He spearheaded the organization of grassroots support for the NNLC and was respected and held in high esteem by almost all the opponents of the traditionalists. His first move towards defection was to ask for forgiveness from Sobhuza for his opposition to the traditionalists. He stopped participation in the activities of the NNLC.

An example of a party whose entire leadership joined the traditionalist camp was the Swaziland Progressive Party (SPP). In a statement released by its president, Dr. Allen Nxumalo, joining Imbokodvo was viewed as being in the interest of the nation.

In pursuance of its motto "unity, justice, and independence", and in view of the fact that the Swaziland Democratic Party has always held national interests as of paramount importance, the National Executive has decided to join the Imbokodvo National Movement. It is the conviction of the Swaziland Democratic Party that any opposition to the Imbokodvo would be meaningless at this stage and indeed would constitute a complete abandonment of all that the Swaziland Democratic Party has stood and fought for since inception (TOS, 19 February, 1965).

The decision of the SDP executive disappointed many who had thought that the party was based on a sound ideological position different from that of the traditionalists. Criticism of the decision also came from other political organizations, whose leadership ironically became guilty of the same action. Arthur Khoza, the Secretary-General of the Ngwane National Liberatory Congress, voiced his party's criticism: 
The whole process certainly can not be hallowed as a symbol of triumph. If the SDP had been based on a different, correct ideology, then its recent action points to shameful defeat, abdication of duty and gravitation from responsibility. Fierce attacks on the Imbokodvo by the SDP during the past few months have suggested that there existed some fundamental differences between the two organizations. Now we know the truth, the cat is out of the bag (TOS, 21 May, 1965).

What surprised most was that some of the leading critics of the action of the SDP resigned from their own parties to join Imbokodvo. Arthur Khoza himself surprised many when in September 1966 resigned from his party the Ngwane National Liberatory Congress. Before that, he was described as "an intelligent, educated, and shrewd member of the NNLC" (Kuper, 1978: 273). He had shown his opposition to Imbokodvo when he said, "Imbokodvo, we all know, is an utterly strange organization whose leadership is appointed, an organization without specific recorded membership" (TOS, 11 June, 1965). In little more than a year after this attack on the Imbokodvo, he joined the ranks of his enemies of yesteryear after resigning from his party. Justifying his resignation, he said:
After more than two years' participation in the emancipation programme of the NNLC, both as external representative and acting Secretary-General, I see the leadership of this organization most regrettably unequal for the task before it. I see the leadership wondering away from the mandate of the main objective of the congress itself - achieving independence through unity, oneness and realistic concrete action (TOS, 2 September, 1966).

From the time of his resignation this member became one of the strongest supporters of the traditional political order in the country. Some commentators have attributed the defections to the overwhelming victory of the Imbokodvo National Movement in the 1964 Legislative Council elections. It was observed:

The decision of some party members to join the Ingwenyama's Imbokodvo National Movement was not surprising. The Imbokodvo's smashing victory at the Legislative Council elections seemed to have weakened the other political parties so much that it was doubtful whether the smaller would survive without drastic 
changes in leadership and in tactics (TOS, 30 April, 1965).

The major weakness of middle class opposition leaders was that they were not guided by clear principles and organizing ideology. To them, politics was an avenue to possible accumulation through the state medium. The victory of the Imbokodvo only offered them a more viable alternative toward the control of state machinery. They were governed more by the desire for personal gain than a belief in the political transformation of the country.

The defections that took place immediately after 1964 indicated the character of the first generation of the Swazi middle class opposition, and influenced the political behaviour of subsequent generations. The most immediate impact of the defections was that the middle class opposition lost support from outside. Previous to the defections, the Swaziland Progressive Party claimed to have received support from Nasser in Egypt, and the Ngwane National Liberatory Congress was believed to have received direct support from Nkrumah in Ghana (Potholm, 1972: 318). Some of the leaders enjoyed the backing of the Committee of Nine in Dar es Salaam. What seem to have disappointed some of the outside organizations is that in different Organization of African Unity meetings some of the defectors had portrayed the Imbokodvo leaders as reactionaries or imperialist puppets. The loss of outside support further weakened the parties and more middle class members swelled the ranks of the Imbokodvo. Sobhuza readily accepted them arguing, "It is their land, their party, their government. Even if they are communists, as some people tell us, they are our sons and, therefore, our communists" (Vilakati, 1979: 272). Most importantly for future generations, was that a new political culture had been created - the culture of conformity and pretence for purposes of personal economic gain.

\section{Post-colonial pretenders and conformers}

The pattern of conformity began by the first generation of middle class politicians gained momentum in the post-colonial period. This was the case because political control was now fully in the hands of the traditionalist who could reward conformers and those who pretended to support the traditional political dispensation. The extent to which supporters of Imbokodvo accumulated land and capital in the post-colonial period, was enough to tempt some of those who were still in opposition (Simelane, 1992). Furthermore, the extent to which appointments to senior government positions favoured those in-line with traditional ideology, excited the greed of most members of the middle class.

The case for conformity in the post-colonial period was made significant by the political actions of the traditionalists. In this period, the 
traditionalists put the middle class opposition under pressure through exclusivist political actions meant to make it difficult for the opposition to access some of the most lucrative offices of the state. The first move in this direction came in 1973 when the traditionalists repealed the independence constitution that had allowed modern political parties to operate in the country. This action narrowed the path to accumulation through the state and the main response of the middle class opposition was collaboration within the terms and framework drawn by the traditionalists. It appears that most members of the middle class opposition realised that the fruits of political office could only be realized if they denounced their earlier political affiliations and embraced traditional politics. From 1973 to the beginning of the 1980s it was Dr. Ambrose Zwane of the Ngwane National Liberatory Congress and few others who stood out as remnants of middle class opposition to traditional ideology (Mthembu, 1992; Vilakati, 1997).

A few years after the repeal of the independence constitution the traditionalists began to define the pattern of political participation in an independent Swaziland. Sobhuza emphasized that all political activity in the country should take place under the Tinkhundla. Louis Picard has defined_Tinkhundla as "meeting places (literally the space outside the cattle corral where Swazi men gather to discuss local affairs and traditional law cases) located in the different rural areas throughout the country" (Picard, 1983: 3; Shongwe, 1983). The Tinkhundla system was used in the colonial period and begins from the people at grassroots level in the chieftainships (SNA, File 352). Sobhuza used it for mobilizing people for the 1964 Legislative Council elections (Picard, 1983: 4). The development of the system was arrested by the continuation of colonial rule as the traditionalists were forced to refer to colonial officials for most of their political actions. During this period, Tinkhundla remained "talking shops and as convenient organizations through which District Commissions [were] able to meet and talk to chiefs" (Butler, 1974: 168-169).

The revival of Tinkhundla after 1973 was meant to be an alternative to the Westminster model of government. Sobhuza, together with the majority of traditionalists, were convinced that the Westminster constitution did not accommodate the primacy of the monarchy in the political affairs of the country. After 1973 Sobhuza began a process of institutionalising the system as an electoral mechanism. The stamp of traditionalism on the system was made evident by the fact that "the king's ultimate control over the procedure is achieved by provisions empowering him to approve all candidates at the Tinkhundla level as well as to nominate some members of the Lower House and the entire Upper House" (Quoted in Picard, 1983: 7). The system became a major inlet to either being a Member of Parliament, Senate or cabinet. It was such traditional structures that the majority of the middle class opposition had rejected in the early 1960s. Yet after 1973, the majority of them were 
prepared to operate through them as an avenue for accumulation through the state pathway.

From 1973 some of the leading pre-independence advocates of PanAfricanist ideas became vociferous defenders of the Tinkhundla system of government. Former opposition leaders such as Simon S. Nxumalo, Arthur Khoza, Allen Nxumalo and George Msibi led the way in the defence of the traditional political system. Educated members of the royal family such as Polycarp Dlamini, Mfanasibili Dlamini and Velaphi Dlamini ably assisted them. Sobhuza was so pleased with winning some members of the middle class opposition that he declared that in the voting process the Swazi should "avoid discrimination of the educated. They are our spies who go to spy on what gave power to certain people to colonize us. They came back to tell and teach us. The point I am trying to make here is that the educated, who understand European ways and the written word should be elected" (Simelane and Bhembe, 2000: 314).

The tendency towards conformity for personal financial gain has disappointed most sections of the Swazi population. One commentator points out:

These officials come out in full support of certain moves by the state even though they are pretty aware of their wicked nature. Most of these officials are well educated and definitely know that they are only faking things because they benefit from the system. This is, to say the least, a betrayal not only of their professions but also the trust that the rest of the nation bestows upon them (TOS, 5 February, 1999).

The readiness to rapidly change political camps made others argue that the country's middle class opposition is governed by the desire to accumulate. Some commentators have blamed the traditionalists for dangling carrots in the face of their opponents.

One of the interesting cases of pretence and conformity is that of Obed Dlamini who also became Prime Ministry from 6 July 1989 to November 1993. When he was appointed Prime Minister he was an active unionist and also a member of the Ngwane National Liberatory Congress. As Prime Minister he served the Tinkhundla system and was praised by supporters of the traditional system as one observer pointed out, "The gentleman was good and always stood up for the Tinkhundla system of government. He tirelessly worked for the Swazi nation" (TOS, 12 May, 1999). Eager to continue enjoying the financial rewards of serving the government of the traditionalists, after the four years in office he stood for election into parliament under the Tinkhundla system, but lost. This seems to have greatly frustrated him but he must have been more frustrated when the King 
did not re-appoint him as Prime Minister. When he was discarded by the system he began to publicly criticize the traditional political system and went further to announce that he was an office bearer of the Ngwane National Liberatory Congress. Following this announcement one commentator pointed out:

Mr. Dlamini after you were defeated at the Nceka elections, you tell us you are a NNLC member. You started to blame the Tinkhundla government and you started to fight the government. What sort of person are you? In case you don't know Mr. Dlamini, you are a lion in a sheep's skin and that's a fact. Now you are president of the NNLC, I've heard, that there are problems there as well as ill-feelings. We have heard also that there is misunderstanding but I am not concerned about that. Recently it was reported that you were fired by your church because of misunderstanding between you and the elders of your church. But Mr. Dlamini are you aware that wherever you are there is trouble. Please do something about that. To all the Swazis, please be aware of hypocrites who call themselves progressives whereas they are destroyers (TOS, 12 May, 1999).

What is intriguing in this case is why this member of the middle class opposition served a system he seemingly hated. The answer seemsto lie within the political actions of most Swazi middle class opposition members. He was willing to pretend he conformed to the system for financial gain. Such action has provoked strong criticism from some observers:

Obed is not worthy to open his mouth against Tinkhundla system of government because he has gained millions from it, he is gaining even now. See the car he drives everyday and the fat cheques he signs, and then see the poor old aged who have to find food from rubbish bins. $\mathrm{He}$ is a leader without love and, therefore, he is a failure. $\mathrm{He}$ is the last person to talk against the Tinkhundla system of government (TOS, 19 January, 1999).

Another commentator pointed out:

His appointment to premiership must have tampered with his political beliefs, or shall I say, his political belief, or shall I say, his central nervous system, so much so that he 
did not consider it much of a crime to run for the election of 1993 under the Tinkhundla system. He lost the race through some dirty tricks perpetrated by some higher ups (TOS, 7 February, 1999).

This opposition member was eager to serve Tinkhundla and to pretend that there was nothing wrong with the system until he felt rejected. Like most of his middle class opposition counterparts, he was willing to sell his principles in return for financial gain. It is no wonder that some observers described him as "The hypocrite of the decade" (TOS, 20 January, 1999).

Another good example of a middle class opposition defector in the post-colonial period is Mbho Shongwe, who was one of the leading activists in the post-Sobhuza II era. This is an era in which civil society had increasingly played an important role in protests against undemocratic practices of the state (Levin, 1997). As a result, there was an emergence of new political organizations such as the People's United Democratic Movement (PUDEMO) (Ndlangamandla, 1994). As a demonstration of his activism and drive towards democratic transformation in the country, Shongwe formed a political party called Swaziland National Front (SWANAFRO) (Vilakati, 1997: 3). Describing the leader of the party's activism against the traditional political framework one commentator said:

Way back in the early 1990s, Mr. Shongwe was active in the formation of his organization, Swaziland National Front (Swanafro). He was seen brushing shoulders with gallant fighters and sometimes engaged in anti Tinkhundla campaigns and rallies organized by movements such as the Peoples United Democratic Front (Pudemo). He was seen moving petitions to Hospital Hill, defying police orders that were stopping him from pursuing processions. He was seen using platforms created by other civic groups to express the deepest sentiments on the status quo (The Swazi Observer, 11 February, 1999).

Up to 1997, there was no doubt that Shongwe was one of the leading opponents of the traditional political system. However, events changed in 1998 when Tinkhundla elections were about to be conducted. Shongwe surprised many when he began to argue for participation in the elections under Tinkhundla. This was the time when most activists were arguing that the elections should boycotted because they were conducted under an undemocratic system. He engaged in public debates speaking the same language as the traditionalists. While most were still surprised by such a 
change in political orientation, the traditionalists were quick to take advantage, and he was appointed as a member of the House of Senate. He readily accepted the appointment much to the disappointment of SWANAFRO supporters. Just like most of his predecessors, he argued that his decision were for the good of the nation. The disappointment of some people was reflected in different statements. One commentator said, "Today [this person] is the biggest traitor and the biggest sell-out like his counterparts who because of greed and the love of money, turn against fellow patriots and joint the enemy" (The Swazi Observer, 11 February, 1999). Yet another observer commented:

Here comes the biggest Tinkhundla recruit because up there he is just nothing except a good example of an animal without a backbone. He comes up on television, he says he likes Tinkhundla government more than SWANAFRO because SWANAFRO never paid him instead it made him poor (TOS, 21 April, 1999).

The contradiction in the actions of the above discussed middle class opposition leaders is characteristic of the political behaviour of most members of the Swazi middle class opposition in the post-colonial period. The idea is always to be noticed so as to be incorporated into the category of those who use the machinery of the post-colonial state for personal gain. Greed and desire for financial gain continue to shape the character of Swazi middle class opposition politics. The Swazi middle class opposition is politically weak on principles and ideology, and easily conforms, or pretends to believe in the traditional political framework, for purposes of grabbing available opportunities for accumulation through the state pathway. They have raised a number of issues to justify their actions. The most common response has been that they aimed at changing the traditional system from within. The assumption here is that once they are appointed to influential positions they will influence a change of policy to democratise the traditional political system. However, time has shown that such an assumption has failed to translate into reality.

\section{Conclusion}

After three decades of British colonial rule Swaziland produced a sizeable element of the middle class. Education and small business has played a crucial role in the emergence and development of this class. This was a class that had a better understanding of the injustices of colonialism and consequently played an important role in undermining the continuation of colonial rule. Swaziland was not alone in this development as all African countries were experiencing such a process of social transformation. Some members of the middle class were at the forefront in the organization of 
modern political parties which aimed at leading the country to independence outside the framework of traditional politics. From this perspective, it can be concluded that at the beginning of the political ferment in the early $1960 \mathrm{~s}$ the world view of most members of the Swazi middle class opposition was fundamentally different from that of the traditional leadership. Many viewed the emergent middle class as an agent for the transformation of the old order.

This paper has demonstrated that the first generation of Swazi middle class opposition members played an important role in the process of decolonisation through leading political movements that were against the continuation of colonial rule and wanted an independent Swazi state organized outside the traditional political framework. It has been indicated that the main opponents of the parties led by middle class members were the traditionalists under the leadership of Sobhuza.

The paper has questioned the ability of the first generation Swazi middle class opposition to construct a genuinely democratic political culture because their politics was aimed at making personal economic gains out of the state. Their opposition to the traditionalists was not based on grounded political principles, but rather on who was to be heir to British colonial rule and thereafter enjoy the benefits. This conclusion arises from the high number of defections after 1964 when it became clear that the traditionalists were certain inheritors of political authority in the country. The paper has, therefore, shown that the politics of the first generation of the middle class opposition, was, as some commentators have noted, nothing more than, 'politics of the stomach.'

The post-colonial period failed to produce a new breed of middle class opposition politicians. Just like their pre-independence predecessors, the majority of them were conformers, while others added the characteristic of being pretenders. The paper has shown that many of them publicly criticized the traditional political system, especially its undemocratic characteristics, however, with each criticism, they were aiming at being noticed by the traditionalists who control the reigns of power. This has been demonstrated by the fact that almost all the leading critics of the traditional political order in the post-colonial period have ended up joining the camp of the traditionalists. While it can be argued that they were 'bought', it should be accepted that this was because they were willing and eager to share the spoils of post-colonial economic plunder. Their political activism was based on greed and desire to accumulate within the neocolonial framework of the post-colonial state.

Much as there is a strong case in arguing that political repression as orchestrated by the traditionalists in the post-colonial period forced conformity on the majority of the members of the middle class and society at large, members of the middle class opposition should not be considered only as victims of such repression. This is the case because they had the 
capacity to make choices. The majority of them were active agents who to a large extent determined the course of their political actions. In the process of making these choices, they limited their role as agents of general political transformation.

\section{References}

Anise, Ladun (1974). "Trends in the Leadership Succession and Regime Change in African Politics Since Independence." African Political Review XVLL, 3 (December).

Biersteker, Thomas J. (1982). Distortion of Development: Contending Perspectives on the Multinational Corporations. London: MIT Press.

Booth, Alan R. (1983). Swaziland: Tradition and Change in a Southern African Kingdom. Boulder: Westview Press.

Burns, Bradford (1982). Latin America: A Concise Interpretive History, Englewood Cliff: Prentice.

Bushnell, D and Maccaulay, Neil (1988). The Emergence of Latin America in the Nineteen Century. Oxford: Oxford University Press.

Butler, Robert (1974). "Local Government in Swaziland," In W.B. Vosloo, D.A. Kotze and W.J.O. Jeppe (eds). Pretoria: Academia.

Callaghy, Thomas M. (1984). The State-Society Struggle: Zaire in Contemporary Perceptive. New York: Columbia University Press.

Clapham, C. (1985). Third World Politics: An Introduction. Madison: Wisconsin University Press.

Clegg, S. Boreham, P. and Daro, G. (1986). Class, Politics and the Economy ${ }_{2}$ London: Routledge and Kegan Paul.

Daniel, J., Simelane, Gladys and Simelane Vusani (eds.) (1975. Politics and Society in Swaziland.. Kwaluseni: University of Botswana, Lesotho and Swaziland.

Evans, P. (1979). Dependent Development: The Alliance of Multinational, State, and Local Capital in Brazil. Princeton: Princeton University Press.

Fanon, F. (1967). The Wretched of the Earth. Harmondsworth: Penguin.

Hagreaves,J. (1979). The end of Colonial Rule in West Africa. London: Macmillan.

Halper, J. (1965). South Africa's Hostages: Basutoland, Bechuanaland, and Swaziland. Baltimore: Penguin.

Hobsbawm, E.J. (1975). The Age of Capital 1848-1875. London: Penguin.

Kalinde, D. (1978). Land, Labour Migration and Politics in Southern Africa:_Botswana, Lesotho and Swaziland. Uppsala.

Kennedy, P. (1988). African Capitalism: The Struggle for Ascendancy. New York: Cambridge University Press.

Kunene, G. (1992). "British Colonial Policy in Swaziland.” Ph.D. thesis, York University. 
Kuper, H. (1978). Sobhuza II: Ngwenyama and King of Swaziland. London: Duckworth.

Levin, R. (1997). When Sleeping Grass Awakens: Land and Power in Swaziland. Johannesburg Witwatersrand University Press.

Lukaks, G. (1974). History and Class Consciousness: Studies in Marxist Dialectics. London: Merlin Press.

Macmillan, H. (1986). "Swaziland: Decolonization and the Triumph of 'Tradition"'. In John Daniel and Michael F. Stephen (eds.). Historical Perspectives on the Political Economy of Swaziland: Selected Articles. Kwaluseni: Social Science Research Unit.

Mamdani, M. (1988). "Contradictory Class Perspectives on the Question of Democracy: The Case of Uganda," in P. Anyang'Nyango (ed.). Popular Struggles for Democracy in Africa. London: Zed Press.

Mazrui, A. (1975). "The Resurrection of the Warrior Tradition in African Political Culture." The Journal of Modern African Studies. 13,1.

Mthembu, C.V. (1992). “A Political Career of Dr. Ambrose Zwane.” B.A. thesis, University of Swaziland.

Ndlangamandla, M. (1993). "The Rule of Sobhuza II and Political Developments After his Death, 1968-1993: The Emergence of the People's United Democratic Movement (PUDEMO)." B.A. thesis, University of Swaziland.

O’Meara (eds.). Southern Africa: Continuing Crisis. London: Macmillan.

Picard, L.A. (1983). "Traditionalism, the Bureaucracy and Political Development: Local Administration in Swaziland." Paper Presented at the 1983 African Studies Association Meeting.

Potholm, C.P. (1966). "Changing Political Configurations in Swaziland." The Journal of Modern African Studies 4,1.

Potholm, C.P. (1972). Swaziland: The Dynamics of Political Modernization. Berkeley: University of California Press.

Poulantzas, N. (1975). Classes in Contemporary Capitalism. London: New Left.

Rasmussen, T. (1969). "Political Competition and One-Party Dominance in Zambia." The Journal of Modern African Studies 7,3.

Sandbrook, R. (1985). The Politics of Africa's Economic Stagnation. Cambridge: Cambridge University Press.

Schatz, S.P. (1977). Nigerian Capitalism. Berkeley: University of California Press.

Selsam M., Goldway, D. and Martel, H. (eds.). (1983). Dynamics of Social Change: A Reader in Marxist Social Science. New York: International Publishers.

Shivji, I.G. (1976). Class Struggles in Tanzania. London: Heinemann.

Shongwe, M. (1983). "Tinkhundla: A Study of Local Government in Swaziland." B.A. thesis, University of Swaziland. 
Simelane, H.S. (1992). "The Post-Colonial State, Class and the Land Question in Swaziland." Journal of Contemporary African Studies 11,1 .

Simelane, H.S. and Bhembe, S. (eds.) (2000). Selected Speeches of King Sobhuza II, Matsapha: Macmillan.

Stevens, R.P. (1966) "Swaziland Political Development," The Journal of Modern African Studies. 1,3.

Thomas, C.Y. (1984). The Rise of the Authoritarian State in Peripheral Societies. New York: Monthly Review Press.

Vengroff, R. (1993). "Governance and the Transition to Democracy: Political Parties and the Party System in Mali," The Journal of Modern African Studies 31,4.

Vilakazi, A. (1979). "Swaziland: From Tradition to Modernity," In Gwendolen M. Carter and Patrick.

Vilakazi, S.J. (1997). "Labour and Politics in Swaziland, 1960-1996." B.A. thesis, University of Swaziland.

\section{Newspapers}

The Swazi Observer, 19 January, 1999.

The Swazi Observer, 11 February, 1999.

Times of Swaziland, 23 March, 1962; 12 December, 1963; 19 February, 1965; 30 April, 1965; 21 May, 1965; 2 September, 1966; 20 January, 1999;

5 February, 1999; 7 February, 1999; 21 April, 1999; 12 May, 1999. 